\title{
ANALISIS TERJEMAHAN KALIMAT YANG MEREPRESENTASIKAN TUTURAN KESANTUNAN POSITIF DALAM NOVEL THE HOST KARYA STEPHENIE MEYER DAN DAMPAKNYA PADA KUALITAS TERJEMAHAN
}

\author{
Chairunnisa, Djatmika, Tri Wiratno \\ Magister Linguistik Penerjemahan Pascasarjana Universitas Sebelas Maret \\ chai.chairunnisa0507@gmail.com
}

\begin{abstract}
Chairunnisa. S131408015. 2016. Analysis of Sentence Translation that Represent Speech Act of Positive Politeness in The Host Novel by Stephenie Meyer and The effects on Quality of Translation. Thesis. Linguistics Post Graduate Program. Sebelas Maret University. Supervisor 1: Prof. Dr. Djatmika, M. A. Supervisor II: Dr. Tri Wiratno, M. A.
\end{abstract}

This research aims is to describe: (1) kinds of positive politeness markers in The Host novel, (2) translation techniques are used in the sentence that represent speech act of positive politeness in The Host novel, (3) the effects of the translation techniques which used by translators in sentences which represent politeness positive against the translation quality in terms of accuracy and acceptability.

This research is a descriptive-qualitative research. The sources of data are the dialogues of The Host novel which represent positive politeness and also informants who assess the quality of the translation. Data were collected by the using analyzing of documents, questionnaires, and forum group discussion (FGD). Data are analyzed by using Spradley's ethnography method.

The result of this research shows that there are 15 kinds of positive politeness strategy markers on The Host novel. The most dominating positive politeness strategy of this data is sub-strategy of use in-group identity marker, as much as $22,49 \%$ of the data. In this research, the translation techniques consist of the application of single translation techniques as much as 102 times, 136 times as many as couplets varian, varian of triplets as many as 34 times, and varian of quartets 2 times. The translation quality from 263 data $(95,64 \%)$ include as accurate translation and 12 data $(4,36 \%)$ are less accurate translation, then 231 data (84\%) includes as acceptable translation, and 44 data $(16 \%)$ are less acceptable translation. The majority of translation techniques have contributed positively to translation quality of The Host novel.

Keywords: positive politeness, translation tehniques, translation quality

\section{Pendahuluan}

Kesantunan berbahasa merupakan aspek penting dalam kehidupan untuk menciptakan komunikasi yang baik di antara penutur dan lawan tutur. Kesantunan berbahasa memiliki peran penting dalam membina karakter positif penuturnya, sekaligus menunjukkan jati diri bangsa. Dalam komunikasi sehari-hari, kita tidak dapat 
setiap saat menyampaikan tuturan dengan cara yang santun, hal tersebut kemungkinan akan menyakiti perasaan lawan tutur. Oleh karena itu, strategi kesantunan digunakan untuk lebih menghargai orang lain maupun diri sendiri.

Kesantunan berbahasa dipengaruhi oleh faktor status, jenis kelamin, usia, dan hubungan kekerabatan. Maka dari itu, makna kesantunan merefleksikan latar budaya yang dianut penutur dengan berorientasi pada sistem kepercayaan, sistem mata pencaharian, hubungan kekerabatan, stratifikasi sosial, dan sistem pernikahan. Faktorfaktor yang mempengaruhi kesantunan menuntut dibuatkan skala kesantunan dari perspektif pragmatik, seperti skala opsional, skala kelangsungan tutur, dan skala jarak sosial. Oleh karenanya, kesantunan berbahasa sendiri bergantung pada sosial budaya, norma dan aturan suatu tempat, nilai atau aturan satu budaya dapat berbeda dengan budaya lain.

Meskipun, fakta menunjukkan perilaku verbal saat ini, dinilai mulai tidak memperhatikan nilai kesopanan dan kesantunan berbahasapun dalam berkomunikasi misalnya, melalui telepon dan handphone. Ketiadaan sapaan, kata penghalus, topik yang tidak pantas, pilihan kata, cara berbicara yang tidak memerhatikan pola pergiliran bicara, bicara menyakiti, kritik pedas, instruksi bossy, pemerasan verbal, intimidasi, ancaman, merupakan sebagian contoh fenomena riil berbahasa di lapangan (Zamzani dkk, 2011).

Melihat fenomena tersebut, bahwa suatu tuturan dapat mengancam muka orang lain bahkan bisa merusak suatu hubungan. Fenomena tersebut membuat peneliti tertarik untuk meneliti tindak tutur yang mengandung kesantunan, terutama kesantunan positif. Dikarenakan kesantunan positif (positive politeness) berhubungan dengan muka positif mitra tutur. Menurut Brown dan Levinson, (1987: 101) muka positif berkenaan dengan 
keinginan agar apa yang dilakukan, apa yang dimiliki, atau apa yang merupakan nilainilai yang diyakini dihargai orang lain, dan diakui sebagai sesuatu yang baik, yang menyenangkan, dan sebagainya. Dalam kesantunan positif, penutur memberikan kesan bahwa penutur mempunyai keinginan yang sama terhadap lawan tutur untuk menunjukkan persahabatan di antara mereka.

Pada hakikatnya, bahasa itu beranekaragam di dalam masyarakat, sehingga terkadang memaksa kita untuk memahami bahasa lain. Hal ini mengarahkan pada pentingnnya sebuah peran penerjemahan. Penerjemahan merupakan suatu proses pengalihan pesan bahasa ke bahasa satu dengan bahasa lainnya. Seorang penerjemah dalam menerjemahkan dari satu bahasa ke bahasa yang lain, bukan hanya bahasanya saja (linguistik) yang harus diketahui tetapi juga aspek-aspek budaya dan kebiasaan dari pemakai bahasa tersebut karena setiap bahasa mempunyai budaya dan kebiasaan yang berbeda. Pemahaman yang memadai tentang aspek bahasa dan non-bahasa dari bahasa sangat diperlukan untuk hasil dalam menyampaikan pesan secara tepat dan akurat. Terutama dalam menerjemahkan tindak tutur yang mengandung kesantunan haruslah akurat karena sudah menyangkut konteks dan budaya setempat. Maka, penerjemahan tersebut diperkirakan akan mempengaruhi kesantunan itu sendiri dan daya pragmatik.

Peneliti tertarik mengkaji kesantunan positif terutama yang ada di dalam novel. Dipilihnya novel sebagai sumber penelitian karena tuturan yang terdapat dalam novel hampir menyerupai tindak tutur langsung yang diucapkan oleh seseorang. Perbedaanya hanya media penyampaiannya saja yang dituang ke dalam bentuk tulisan dan bersifat non-verbal.

Tindak tutur yang terdapat di dalam suatu novel sangat menarik untuk dikaji, karena dalam setiap tokoh yang diciptakan pengarang tentu memiliki karakter yang 
berbeda-beda. Melalui karakter yang berbeda inilah maka setiap tindak tutur yang diucapkan pun akan memiliki ragamnya sendiri. Maka dari itu, tindak tutur yang terdapat dalam suatu teks atau wacana tidak kalah menarik untuk dikaji dibandingkan dengan tindak tutur langsung yang bersifat verbal. Khususnya, tindak tutur yang terdapat pada novel-novel yang sudah diterjemahkan.

Pada novel-novel berbahasa asing yang telah diterjemahkan ke dalam bahasa Indonesia, dapat ditemukan tindak tutur yang telah diterjemahkan yang menyesuaikan dengan budaya pembaca sasaran. Kadang kala, tindak tutur tersebut juga mengalami perubahan dari segi strategi kesantunan yang terdapat dalam teks bahasa sumber dan teks terjemahannya. Perubahan strategi kesantunan yang terjadi di bahasa sasaran membuat tindak tutur yang ada di dalam novel terjemahan memiliki derajat kesantunan yang berubah pula.

Berdasarkan pembahasan pada latar belakang masalah, maka dapat dihasilkan beberapa tujuan penelitan yaitu; pertama, Untuk mengidentifikasi dan mendeskripsikan jenis-jenis penanda kesantunan positifdalam novel The Host karya Stephenie Meyer dan terjemahannya. Kedua, Untuk mengidentifikasi teknik penerjemahan yang digunakan pada kalimat yang merepresentasikantuturan kesantunan positifdalam novel The Host karya Stephenie Meyer. Dan ketiga, Untuk mendeskripsikan dampak dari teknik yang digunakan penerjemah terhadap kualitas terjemahan dari segi keakuratan dan keberterimaan pada kalimat yang merepresentasikantuturan kesantunan positifdalam novel The Host karya Stephenie Meyer.

Pada penelitian ini, peneliti menggunakan teori teknik penerjemahan dari Molina \& Albir (2002). Alasan mengapa peneliti menggunakan teknik penerjemahan yang diusulkan Molina \& Albir (2002) dikarenakan teknik penerjemahan tersebut 
sangat terperinci dan jelas, memudahkan peneliti dalam mengklasifikasi setiap data yang diteliti. Molina \& Albir (2002) dalam Meta XLVII, mengemukakan teknik penerjemahan meliputi, teknik kesepadanan lazim, teknik kompresi linguistik, teknik peminjaman, teknik modulasi, teknik kompensasi, teknik reduksi, teknik amplifikasi, teknik adaptasi, teknik amplifikasi linguistik, teknik transposisi, teknik transposisi, teknik generalisasi, teknik variasi, teknik partikulasi, teknik kreasi diskursif, teknik kalke, teknik deskripsi, teknik harfiah, dan teknik subtitusi.

Sementara itu, untuk uji hasil kualitas terjemahan untuk aspek keakuratan menggunakan accuracy rating instrument yang dikemukakan Nababan (2004). Nababan mengadaptasi instrumen dari Nagao, Tsuji, dan Nakamura untuk mengukur tingkat akurasi tersebut berdasarkan tiga kriteria dengan skala 1 sampai 3 dan untuk aspek keberterimaan menggunakan instrumen keberterimaan berdasarkan tiga kriteria dengan skala 1 sampai 3. Kualitas terjemahan diukur melalui dua aspek yang akan dijadikan acuan, yakni keakuratan dan keberterimaan. Aspek-aspek ini menjadi pedoman bagi para penerjemah agar bisa menghasilkan terjemahan dengan tingkat keakuratan dan keberterimaan yang tinggi.

Untuk teori kesantunan positif berlandasan teori menurut Brown \& Levinson (1987) dengan alasan bahwa teori yang diungkapkan oleh Brown \& Levinson (1987) membahas strategi kesantunan dengan lebih rinci dan klasifikasi yang lebih jelas. Strategi ini oleh Brown dan Levinson (1987: 103-129) dirinci lagi menjadi lima belas macam sub-strategi dengan memberikan intonasi maupun penekanan melalui tuturannya; sub-strategi memberi perhatian pada lawan tutur, sub-strategi membesarbesarkan minat, persetujuan, simpati terhadap lawan tutur, sub-strategi meningkatkan ketertarikan terhadap lawan tutur, sub-strategi menggunakan identitas kelompok, sub- 
strategi mencari dan mengusahakan persetujuan, sub-strategi menghindari ketidaksetujuan, sub-strategi menunjukkan hal-hal yang dianggap mempunyai kesamaan, sub-strategi menyatakan lelucon, sub-strategi mempresuposisikan bahwa penutur memahami keinginan lawan tuturnya, sub-strategi membuat penawaran atau janji, sub-strategi menunjukkan rasa optimisme, sub-strategi berusaha melibatkan lawan tutur dan penutur dalam suatu kegiatan tertentu, sub-strategi memberikan dan meminta alasan sebanyak, sub-strategi mengharap atau menuntut timbal balik, dan sub-strategi memberikan penghargaan.

\section{Metode}

Penelitian ini merupakan penelitian penerjemahan yang bersifat deskriptif kualitatif dan merupakan studi kasus terpancang. Disebut sebagai penelitian kualitatif karena penelitian ini mengkaji mengenai masalah sosial yang ada di masyarakat (Creswell, 1998: 15), dalam hal ini bidang kajiannya adalah analisis terjemahan kalimat yang merepresentasikan tuturan kesantunan positif dalam novel The Host karya Stephenie Meyer dan dampaknya bagi kualitas terjemahannya.

Penelitian ini juga disebut penelitian deskriptif karena bertujuan mendeskripsikan secara rinci fenomena-fenomena yang dikaji di lapangan (Sutopo, 2002:111). Penelitian ini bisa dikategorikan dalam penelitian studi kasus terpancang atau dengan kata lain, yaitu embedded case study (Sutopo, 2006:137), karena sebelum penelitian dilaksanakan, peneliti telah menentukan rumusan masalah atau kasusnya terlebih dahulu.

Di dalam penelitian ini, peneliti menggunakan metode dengan membagikan kuesioner dan melakukan focus group discussion (FGD) khusus dengan para informan (rater), yang dengan kata lain yaitu menggunakan pendekatan etnografi. Penelitian 
dengan pendekatan etnografi menuntut peneliti untuk melakukan penelitiannya langsung di lokasi tersebut, yang bisa juga disebut sebagai studi lapangan. Dengan demikian, peneliti mendapatkan data yang lebih konkret dan tentu saja absah.

Lokasi penelitian ini merupakan media berupa novel The Host karya Stephenie Meyer yang ber-setting di Amerika. Aktor atau partisipannya adalah para tokoh dalam novel ini, dan peristiwanya berupa tindak tutur yang mengandung kesantunan positif yang diujarkan oleh para tokohnya.

Sementara itu, pada teknik cuplikan dilakukan pada pemilihan novel The Host karya Stephenie Meyer sebagai sumber data. Novel ini dipilih karena menyediakan data yang cukup mengenai kalimat yang merepresentasikantuturan kesantunan positif (positive politeness). Teknik cuplikan juga diterapkan pada pemilihan informan yang menilai kualitas terjemahan kalimat yang merepresentasikan tuturan kesantunan positif (positive politeness) pada novel The Host karya Stephenie Meyer dan terjemahannya. Informan yang terdiri dari tiga pembaca ahli (rater) menilai kualitas dari segi keakuratan dan tiga rater menilai kualitas tingkat keberterimaan.

Pada penelitian ini menggunakan dua jenis sumber data, yakni dokumen dan informan. Dokumen dalam penelitian ini adalah novel yang berjudul The Host karya Stephenie Meyer dan terjemahannya.Sumber data yang kedua adalah informan. Data yang dikaji dalam penelitian ini terdiri dari dua jenis yaitu data primer dan data sekunder.Data primer diperoleh dengan cara mengambil kalimat yang merepresentasikan percakapan kesantunan positif (positive politeness) dalam novel The Host karya Stephenie Meyer dan terjemahannya, juga hasil dari kuesioner sekaligus focus group discussion terhadap para rater mengenai keakuratan dan keberterimaan. 
Kemudian, data sekunder yang digunakan oleh peneliti adalah informasi mengenai novel The Host karya Stephenie Meyer dan hasil penelitian dari para peneliti sebelumnya yang kemudian digunakan sebagai bahan referensi untuk penelitian ini.

Untuk teknik pengumpulan data pada penelitian ini dengan mengkaji dokumen (content analysis), kuesioner dan focus group discussion (diskusi kelompok terarah). Analisis dokumen (content analysis) dilakukan dengan menggunakan teknik simak catat. Pengkajian dokumen dilakukan untuk menemukan informasi yang sesuai dengan kebutuhan dan tujuan penelitian. Dengan demikian, untuk tahapan analisis datanya menggunakan tahapan analisis etnografis. Dalam menganalisis data, peneliti menggunakan empat teknik analisis data yang diadaptasi oleh Spradley (2007:132-133). Keempat teknik analisis data tersebut, yaitu: analisis domain, analisis taksonomi, analisis komponensial, dan analisis tema budaya.

Kuesioner ini digunakan untuk mendapatkan data mengenai kualitas terjemahan yang mencakup aspek keakuratan dan keberterimaan. Tahapan pengumpulan data selanjutnya adalah focus group discussion (diskusi kelompok terarah). Tahapan ini dilakukan dengan cara wawancara kelompok agar data yang diperoleh lebih mantap karena sudah dibahas oleh banyak narasumber sebagai anggota dari diskusi kelompok.

\section{Hasil dan Pembahasaan}

\section{Jenis-Jenis penanda strategi kesantunan positif}

Data yang terkumpul dari kalimat yang merepresentasikan tuturan kesantunan positif dalam novel The Host dan terjemahannya berjumlah 275 unit data. Dari kumpulan data tersebut, ditemukanlah beberapa hal. Temuan pertama, mengenai penanda strategi kesantunan positif pada kalimat yang merepresentasikan tuturan 
kesantunan positif. Dari hasil temuan dan pembahasan, ditemukan 15 jenis sub-strategi yang biasa digunakan dalam kesantunan positif meliputi, sub-strategi memberi perhatian pada lawan tutur sebanyak $47(16,26 \%)$ unit data, sub-strategi membesar-besarkan minat, persetujuan, simpati terhadap lawan tutur sebanyak 37 (12,80\%) unit data, substrategi meningkatkan ketertarikan terhadap lawan tutur sebanyak $8(2,77 \%)$ unit data, sub-strategi menggunakan identitas kelompok sebanyak $65(22,49 \%)$ unit data, substrategi mencari dan mengusahakan persetujuan sebanyak $28(9,69 \%)$ unit data, substrategi menghindari ketidaksetujuan sebanyak $10(3,46 \%)$ unit data, sub-strategi menunjukkan hal-hal yang dianggap mempunyai kesamaan sebanyak $7(2,42 \%)$ unit data, sub-strategi menyatakan lelucon sebanyak $6(2,08 \%)$ unit data, sub-strategi mempresuposisikan bahwa penutur memahami keinginan lawan tuturnya sebanyak 7 $(2,42 \%)$ unit data, sub-strategi membuat penawaran atau janji sebanyak $13(4,50 \%)$ unit data, sub-strategi menunjukkan rasa optimisme sebanyak $26(9 \%)$ unit data, sub-strategi berusaha melibatkan lawan tutur dan penutur dalam suatu kegiatan tertentu sebanyak 15 $(5,19 \%)$ unit data, sub-strategi memberikan dan meminta alasan sebanyak $10(3,46 \%)$ unit data, sub-strategi mengharap atau menuntut timbal balik sebanyak $7(2,42 \%)$ unit data, dan sub-strategi memberikan penghargaan sebanyak $3(1,04 \%)$ unit data.

Dari 275 data, penulis menemukan bahwa terdapat dua kombinasi strategi penanda kesantunan positif, yakni satu penanda kesantunan positif $(94,18 \%)$ dan dua penanda kesantunan positif $(5,82 \%)$. Persentase temuan masing-masing kombinasi strategi penanda kesantunan positif adalah sebagai berikut:

\begin{tabular}{cccc}
\multicolumn{4}{c}{ Tabel 1. Temuan Kombinasi Penanda Strategi Kesantunan Positif } \\
\hline No & Kombinasi Strategi Penanda & Jumlah & Persentase \\
& Kesantunan Positif & & $(\%)$ \\
\hline 1. & Satu Penanda Kesantunan Positif & 259 & $94,18 \%$ \\
2. & Dua Penanda Kesantunan Positif & 16 & $5,82 \%$ \\
& Total & 275 & $100 \%$
\end{tabular}


Hal ini menunjukkan bahwa penggunaan tuturan yang mengandung kesantunan positif banyak digunakan oleh karakter pada novel The Host. Penulis menemukan bahwa ada 2 faktor yang mempengaruhi jumlah data kesantunan positif yang banyak, yaitu tema novel dan hubungan sosial tokoh dalam novel.

Tema novel termasuk novel percintaan dan tema ini mempengaruhi dialogdialog dalam novel. Kisah dalam novel adalah percintaan yang dibumbui konflik, dan dialog-dialog sangat didominasi oleh percakapan yang menggunakan panggilan keakraban. Faktor ini mempengaruhi jumlah dialog yang mengandung unsur kesantunan positif.

Faktor kedua yang mempengaruhi banyaknya jumlah penggunaan tuturan kesantunan positif adalah hubungan sosial para tokoh. Karakter-karakter yang ada dalam novel didominasi oleh status sosial yang setara (equal) yang mana rata-rata penutur dan lawan tutur sudah mengenal sangat baik sekaligus memiliki tingkat kedekatan yang akrab (intimate) karena kesantunan positif pada umumnya menekankan segi kedekatan, keakraban, solidaritas, persahabatan, dan hubungan baik antara penutur dan petutur.

Dari hasil temuan, ditemukan data sejumlah $4(1,46 \%)$ unit dari total 275 data yang strategi kesantunannya mengalami perubahan derajat kesantunan. Perubahan derajat strategi kesantunan terlihat dalam menganalisis teknik penerjemahan yang dipakai penerjemah. Dari hasil temuan menunjukkan bahwa ada beberapa unit data pada saat menerjemahkan kalimat yang merepresentasikan tuturan kesantunan positif, penerjemah hanya menerjemahkan sesuai dengan isi pesan tanpa melihat dari konteks dan budaya bahasa sumber. Penerjemahan tersebut akan mempengaruhi derajat kesantunan yang ada di dalam kalimat yang meprepresentasikan tuturan kesantunan 
positif karena pertimbangan konsep budaya tidak dapat dipisahkan dalam penerjemahan.

Dalam penerjemahan, pertimbangan kesantunan berhubungan erat dengan tuturan bahasa sumber yang harus diterjemahkan oleh penerjemah. Penerjemahan diharapkan dapat mengemas tuturan yang ada dengan mempertimbangkan keakuratan pesan. Di sisi lain, aspek kesantunan ini juga harus diimbangi dengan pertimbangan dalam budaya dalam bahasa sasaran. Dalam penerjemahan, aspek ini disebut dengan keberterimaan yang berarti bahwa penerjemahan harus dapat menghasilkan terjemahan yang lazim serta sesuai dengan budaya dan kaidah bahasa sasaran (Hornby, 1988:85). Oleh karena itu, meskipun Brown \& Levinson (1987) mengatakan bahwa kesantunan bersifat universal dalam semua bahasa, pembahasaan mengenai strategi kesantunan positif dalam penerjemahan tetap tidak dapat dipisahkan dari kesopanan. Pertimbangan budaya inilah yang menjadi salah satu alasan mengapa pada terjemahan kalimat yang merepresentasikan tuturan kesantunan positif ditemukan perubahan derajat kesantunan.

$$
\text { Berdasarkan hasil temuan penelitian pada sejumlah kalimat yang }
$$
merepresentasikan tuturan yang mengandung kesantunan positif pada novel The Host dan terjemahannya, menunjukkan bahwa para penutur dan lawan tutur diketahui sudah mengenal satu dengan yang lain. Hal tersebut, diketahui dari konteks cerita. Namun, beberapa tidak memiliki hubungan dekat ataupun kekeluargaan. Akan tetapi, terdapat juga kalimat yang merepresentasikan tuturan yang mengandung kesantunan positif yang menunjukkan bahwa penutur dan lawan tutur diketahui tidak mengenal satu dengan yang lain dan dari beberapa tuturan diketahui dari konteks cerita tidak memiliki hubungan dekat dan kekeluargaan. Dengan demikian, penerapan strategi kesantunan positif tidak hanya digunakan pada orang yang dikenal tetapi juga pada orang-orang 
yang tidak dikenal. Hal tersebut untuk mendekatkan jarak sosial antara penutur dan lawan tutur.

Dapat disimpulkan dari hasil di atas, bahwa kesantunan positif dapat memperbaiki secara langsung wajah positif lawan tutur. Dalam penggunaan strategi ini, kesantunan positif mencoba untuk meningkatkan keakraban, mempersempit kesenjangan pada kekekuasaan, dan penggunaannya lebih banyak menggunakan bahasa yang informal. Penggunaan kesantunan positif biasanya mencoba untuk meminimalkan jarak antara penutur dan lawan tutur dengan mengekspresikan keramahan dan keinginan yang kuat pada penutur untuk memenuhi kebutuhan lawan tutur untuk dihormati.

\section{Teknik Penerjemahan dalam Terjemahan Kalimat yang Merepresentasikan Kesantunan Positif}

Dari 275 data yang dianalisis, ditemukan bahwa terjemahan kalimat yang merepresentasikan tuturan kesantunan positif dalam novel The Host karya Stephenie Meyer menggunakan 12 jenis teknik penerjemahan dengan frekuensi penerapan empat varian teknik. Kedua belas teknik tersebut meliputi antara lain teknik kesepadanan lazim sebanyak 273 kali (56,52\%), teknik kompresi linguistik sebanyak 21 kali (4,35\%), teknik peminjaman sebanyak 64 kali (13,25\%), teknik modulasi sebanyak 29 kali (6\%), teknik kompensasi sebanyak 8 kali (1,66\%), teknik reduksi sebanyak 20 kali $(4,14 \%)$, teknik amplifikasi sebanyak 23 kali (4,76\%), teknik adaptasi sebanyak 7 kali $(1,45 \%)$, teknik amplifikasi linguistik sebanyak 25 kali (5,18\%), teknik transposisi sebanyak 7 kali $(1,45 \%)$, teknik variasi 1 kali $(0,21 \%)$ dan teknik partikulasi sebanyak 5 kali $(1,04 \%)$. Persentase temuan masing-masing varian teknik adalah sebagai berikut. 
Tabel 2. Temuan Varian Teknik Penerjemahan

Kalimat Merepresentasikan Tuturan yang Mengandung Kesantunan Positif

Pada Novel The Host

\begin{tabular}{|c|c|c|c|}
\hline No & Varian Teknik Penerjemahan & Jumlah & Persentase $(\%)$ \\
\hline 1. & Tunggal & 102 & $37,45 \%$ \\
\hline 2. & Kuplet & 136 & $49,45 \%$ \\
\hline 3. & Triplet & 34 & $12,36 \%$ \\
\hline 4. & Kwartet & 2 & $0,73 \%$ \\
\hline Total & & 275 & $100 \%$ \\
\hline
\end{tabular}

Secara keseluruhan, teknik penerjemahan yang ditemui pada kalimat yang merepresentasikan tuturan kesantunan positif pada penelitian ini mampu menyampaikan pesan yang terdapat pada Bsu secara jelas ke Bsa. Hal ini diyakini penulis berdasarkan hasil temuan dan analisis bahwa tidak terdapat tuturan Bsu yang tidak diterjemahkan atau terjemahannya menyimpang jauh dari teks aslinya sehingga hal tersebut, berdampak langsung tehadap kualitas terjemahan kalimat yang mereprentasikan tuturan kesantunan positif.

\section{Kualitas Terjemahan Kalimat Yang Merepresentasikan TuturanKesantunan Positif Pada Novel The Host}

Dari 275 kajian data, kualitas terjemahan kalimat yang merepresentasikan tuturan kesantunan positif pada novel The Host cenderung memiliki kualitas yang baik. Terjemahan akurat mendominasi penelitian ini, dibandingkan dengan terjemahan yang kurang akurat atau tidak akurat. Begitu juga dengan tingkat penilaian keberterimaan. Persentase tiap-tiap aspek tingkat kualitas keakuratan dan keberterimaan tinggi adalah untuk hasil penerjemahan yang baik cenderung dominan, seperti tingkat keakuratan mempunyai $95,64 \%$ dan kebeterimaan $84 \%$. Dilihat dari persentase tersebut dapat disimpulkan bahwa penerapan temuan teknik cenderung baik terhadap kualitas terjemahan kalimat yang merepresentasikan tuturan kesantunan positif pada novel The Host. Berdasarkan frekuensi penggunaan teknik penerjemahan, teknik kesepadanan 
lazim, peminjaman, amplifikasi linguistik, dan modulasi mendominasi penelitian ini. Keempat teknik ini cenderung memberikan nilai positif pada kualitas terjemahan.

Dari 275 data tuturan, sebanyak 263 data $(95,64 \%)$ merupakan terjemahan yang akurat, dan 12 data $(4,36 \%)$ termasuk terjemahan kurang akurat. Tidak ditemui data tuturan yang terjemahannya tidak akurat. Dari hasil tingkat keberterimaan, sebanyak 231 data (84\%) merupakan terjemahan yang berterima dan 44 data (16\%) termasuk terjemahan kurang berterima, dan tidak ditemui pula data tuturan yang terjemahannya tidak berterima.

\section{Simpulan dan Saran}

\section{Simpulan}

Berdasarkan hasil temuan dan pembahasan mengenai analisis kalimat yang merepresentasikan tuturan kesantunan positif dalam novel The Host dan terjemahannya, dapat ditarik kesimpulan bahwa dari 275 data unit data yang mereprsentasikan kesantunan positif ditemukan 15 jenis sub-strategi kesantunan positif. Sub-strategi kesantunan positif yang paling dominan atau yang paling sering muncul ialah substrategi penanda menggunakan identitas kelompok sebanyak 65 data atau 22,49\%.

Selain itu, ditemukan pula 4 unit data kalimat yang merepresentasikan tuturan kesantunan positif yang mengalami perubahan derajat kesantunan. Penyebab dari perubahan derajat kesantunan pada tuturan di Bsa disebabkan oleh penerapan teknik penerjemahan.

Untuk penerapan teknik penerjemahan di dalam penelitian ini ditemukan 12 jenis teknik terjemahan yang diterapkan dalam varian tunggal, kuplet, triplet, dan kwartet dengan total frekuensi kemunculan sebanyak 483 kali. Secara keseluruhan, teknik penerjemahan yang ditemui pada kalimat yang merepresentasikan tuturan 
kesantunan positif pada penelitian ini mampu menyampaikan pesan yang terdapat pada Bsu secara jelas ke Bsa.

Sementara itu, untuk hasil uji kualitas secara keseluruhan disimpulkan bahwa terjemahan strategi kesantunan positif dalam novel The Host memiliki keakuratan dan keberterimaan yang tinggi. Akhir dari penelitian ini, penulis menghubungkan semua poin yang menjadi rumusan masalah, dan menyimpulkan bahwa bahwa kesantunan positif dapat memperbaiki secara langsung wajah positif lawan tutur.

\section{Saran}

Setelah melakukan analisis data, maka penulis berkesimpulan bahwa penelitian ini masih dapat dikembangkan lebih lanjut lagi. Maka dari itu, penulis mencoba memberikan masukan bagi peneliti lain yang tertarik dengan penelitian penerjemahan dengan menggunakan pragmatik, khususnya mengenai kesantunan berbahasa.

Penelitian lanjutan yang dapat dikembangkan dari penelitian ini yaitu, penelitian serupa dengan penelitian ini bisa dilakukan tetapi dengan fokus data bukan pada kalimat tetapi hanya pada kata yang mengindikasikan kesantunan positif atau bisa juga menganalisis kesantunan positif dengan dikaitkan dengan tindak tutur seperti kesantunan positif pada tindak tutur komisif. Peneliti lainya juga dapat memilih sumber data yang berbeda, misalnya terjemahan audiovisual dalam bentuk film atau dubbing atau peneliti lainya juga masih dapat mengkaji kesantunan positif pada novel tetapi menggunakan genre yang berbeda. 


\section{DAFTAR PUSTAKA}

Brown, P \& Levinson, S. 1987. Politeness: some universal in language usage. Cambridge: Cambridge University Press.

Catford, J. 1980. A linguistic theory of translation. Oxford:Oxford University Press.

Creswell, J. W. 1998. Research designs: qualitative inqury and research design: choosing among five traditions. Thousand Oaks; London: SAGE.

Hornby, S. 1988. Translation Studies: an intergrated approach. Amsterdam and Philadephia: John Benjamin Publishing.

Meyer, S. 2008. The host. New York: Little, Brown and Company.

Meyer, S. 2009. The host:sang pengelana. Jakarta: PT Gramedia Pustaka Utama.

Molina, L \& A. H. Albir. 2002. Translation technique and revisited: a dynamic and functional approach, in Meta: Translator's Journal. XL VII, 4.

Nababan, M. R. 2004. Strategi penilaian kualitas terjemahan, dalam Jurnal Linguistik Bahasa. Vol. 2, No. 1 Hal 54-65.

Spradley, J. P. 1980. Participant observation. New York: Holt, Reinhart and Winston.

Spradley, J. 2007. Metode etnografi. Yogyakarta: Tiara Wacana.

Sutopo, H. B. 2002. Metodologi penelitian kualitaitf dasar teori dan terapannya dalam penelitian. Surakarta: UNS Press.

Sutopo, H. B. 2006. Metodologi penelitian kualitatif: dasar teori dan terapannya dalam penelitian. surakarta: universitas sebelas maret.

Zamzani, Musfiroh, T., Maslakhah, S., Listyorini, A. \& Eny, Y. 2011. Pengembangan alat ukur kesantunan Bahasa Indonesia dalam interaksi sosial bersemuka, dalam Jurnal UNY Vol. 17 no. 2. 